\title{
АНАЛІТИЧНІ ТЕРМІНИ ЯК ОСОБЛИВІ ОНОМАСІОЛОГІЧНІ ЗНАКИ В МОВНІЙ КАРТИНІ СВІТУ УКРАЇНЦІВ
}

\author{
ЛІЛІЯ ГАРАЩЕНКО \\ Харківський національний педагогічний університет імені Г. С. Сковороди, \\ Харків - Україна \\ TERMINY ANALITYCZNE \\ JAKO ORYGINALNE ZNAKI ONOMAZJOLOGICZNE \\ W JĘZYKOWYM OBRAZIE ŚWIATA UKRAIŃCÓW \\ LILIA HARASZCZENKO \\ Charkowski Narodowy Uniwersytet Pedagogiczny im. H. Skoworody, \\ Charków - Ukraina
}

STRESZCZENIE. W artykule określone zostało miejsce terminów analitycznych wśród terminologii naukowej i technicznej w językowym obrazie świata Ukraińców. Na materiale językowym wyznaczono onomazjologiczną strukturę konstrukcji analitycznych i procesów poznawczych będących podstawą ich tworzenia.

\section{ANALYTICAL TERMS AS SPECIAL ONOMASTIC SIGNS IN THE UKRAINIANS' LANGUAGE MAP OF THE WORLD}

\section{LILIYA GARASHCHENKO}

H. S. Skovoroda Kharkiv National Pedagogical University, Kharkiv — Ukraine

ABSTRACT. The place of analytical terms of scientific and technical terminology in the Ukrainians' language map of the world is defined in the article. Onomastic structures of analytical constructions and cognitive processes which lie in the basis of their creation have been defined after thorough studying of a wide linguistic material.

Д

ослідження динаміки розвитку лексичної системи української мови в різні історичні періоди міститься в площині найбільш актуальних мовознавчих студій. Останнім часом науковці щодалі більше звертають увагу на те, як світ відображається у свідомості людини і як сприяє цьому лексична система мови. Особливий інтерес викликає функціонування знакових одиниць, що позначають наукові поняття.

Найдинамічнішою частиною словникового складу мови є лексика термінологічних систем, що активно поповнюється й змінюється. Дослідження структури, організації та функціонування термінологічних систем дає змогу поглибити уявлення про певну сферу людської діяльності, специфіку її пізнання носіями відповідної мови й культури, з'ясувати закономірності творення та кодифікування термінів і тенденції розвитку галузевих терміносистем. Стан термінологіï, іiі досконалість, багатство свідчать про науковий прогрес у тій чи тій галузі знань, а також про можливості конкретної мови виражати наукові поняття й ідеї. 
За останні десятиліття здобутки українського термінознавства є досить вагомими. Про це свідчить поява значної кількості наукових праць, присвячених загальним теоретичним проблемам термінознавства (В. Іващенко, Т. Кияк, I. Кочан, А. Крижанівська, Г. Наконечна, Т. Панько, Л. Симоненко та ін.) і дослідженню окремих галузевих терміносистем (І. Волкова, С. Дорошенко, Н. Книшенко, Л. Малевич, Н. Нікуліна, О. Романова, О. Чуєшкова, Н. Цимбал та ін.). На сучасному етапі розвитку українське термінознавство має кілька напрямів, що скеровні на „осмислення закономірностей розбудови терміносистем, способів лінгвістичного відображення різних невербальних елементів картини світу"1. У цьому аспекті видається актуальним вивчення номінативних процесів, що відбуваються в кожній терміносистемі з подальшим прогнозуванням розвитку української термінології загалом.

Термінологічна номінація - це особливий процес розумової діяльності людини, зумовлений взаємодією зовнішніх і внутрішніх чинників. На відміну від загальномовної номінації (часто стихійної, невпорядкованої), вона має специфіку, пов' язану передусім із особливостями терміна як значущої одиниці, що відображає довкілля й водночас є наслідком та інструментом пізнавальної діяльності людини.

Поняття, що з'являється в галузі науки й техніки, закономірно потребує найменування. Наявність значення в найменуванні наукового поняття виявляється в процесі взаємодії терміна з тезаурусом реципієнта: термін набуває значення тоді, коли реципієнт, сприймаючи його, формує у своїй свідомості когнітивне утворення, що максимально наближене до авторського ${ }^{2}$. Саме тому під час термінотворення переважає когнітивний чинник, що уможливлює встановлення тісних взаємозв'язків між мовною й концептуальною картинами світу. Під МКС розуміємо характер відображення в мові концептуальної картини світу, а також мовні засоби вираження знань про неї. „Картина світу - те, яким зображує світ людина у своїй уяві, - феномен більш складний, ніж МКС, тобто та частина концептуального світу людини, що прив'язана до мови й відображається в мовних формах"з.

Науково-технічний прогрес сприяє не лише бурхливому розвитку науки й техніки, але й вносить істотні зміни в лінгвістичну модель світу появою як окремих термінів і терміносполук, так і цілих терміносистем. Вироблення єдиних принципів і засобів практичного термінотворення має грунтуватися на загальній теорії номінації (в ії ономасіологічному та дериваційному аспектах) ${ }^{4}$.

Як відомо, способами творення термінологічних одиниць є: 1) використання загальновживаних слів для позначення певного наукового поняття (термінологізація); 2) перенесення готового терміна з однієї галузі в іншу (ретермінологізація); 3) запозичення та калькування; 4) використання наявних у мові словотвірних моделей або іншомовних терміноелементів; 5) використання словосполучень для найменування наукових понять (у різних терміносистемах вони становлять до 70\% від загальної кількості термінів) ${ }^{5}$. Поява термінологічних сло-

${ }^{1}$ Л. Туровс ька, Типологічне термінознавство кіния XX-початку XXI cm. в Украӥні, [в:] „Вісник Національного університету «Львівська політехніка»”. Серія „Проблеми української термінології” 2012, № 733, с. 49.

${ }^{2}$ Н. В. В ас ил ье в а, Термин, [в:] Лингвистический энциклопедический словарь, под. ред. В. Н. Я рце в ой, Москва 1990, с. 508-509.

${ }^{3}$ Роль человеческого фактора в языке: Язык и картина мира, Москва 1988, с. 142.

${ }^{4}$ В. П. Даниленко, Л. И. Скворцов, Лингвистические проблемы упорядочения научнотехнической терминологии, [в:] „Вопросы языкознания”, 1981, № 1, с. 11.

5 Л. О. С им он енко, Термін, [в:] Українська мова: Енциклопедія, редкол.: В. М. Русанівський, О. О. Тараненко та ін., Київ 2004, с. 682. 
восполучень пов'язана з аналітичним способом термінотворення, сутність якого полягає в поєднанні двох або більше повнозначних слів, певним чином між собою пов'язаних, що означають одне поняття.

На думку мовознавців, аналітичний спосіб термінотворення є одним з основних поряд із семантичним і морфологічним ${ }^{6}$. Причини активності й продуктивності цього типу творення термінів і входження їх у терміносистеми окремих галузей знань криються в тому, що, на відміну від термінів-слів, термінисловосполучення виявляють більшу здатність до конкретизації значень завдяки їхній можливості надавати додаткові уточнювальні галузеві характеристики загальновживаним словам.

У сучасному українському та зарубіжному мовознавстві сформувалися різні погляди на статус аналітизму як такого. Здебільшого під аналітизмом мається на увазі розчленованість лексичного й граматичного значення, але в цьому разі не враховано статус аналітичних одиниць та їхню ярусну приналежність. А. Загнітко, наприклад, зазначає, що постання й розвиток аналітичних форм, конструкцій пов'язані з процесом граматизації словосполучень. Остання зумовлена послабленням або втратою лексичного значення одного з компонентів словосполучення ${ }^{7}$. Розвиток аналітичних форм зі словосполучень, на думку вченого, зумовлює переважно витіснення флективних форм, що детермінує збільшення кількості аналітичних форм. Як наголошує А. Загнітко, аналіз граматичного аналітизму повинен грунтуватися на простеженні специфіки вияву розчленованих форм на морфологічному й синтаксичному ярусах мовної системи ${ }^{8}$.

О. Дубова вважає, що випадки використання двох або більше повнозначних слів, порядку слів і контексту як засобів вираження певних типів значень повинні залишатися поза межами морфологічного аналітизму, тому що порядок слів, сполучення з іншими повнозначними словами є засобами вираження синтаксичної семантики, співвіднесеної з певними грамемами морфологічних категорій 9 .

За спостереженнями I. Мельчука, під аналітичним, протиставленим синтетичному, головним чином, мають на увазі закономірність вияву двох або більше синтаксично пов'язаних словоформ там, де цілком логічним був би вияв тільки однієї словоформи. На думку названого вченого, в суворо термінологічному вжитку термін ,аналітичний” можливий тільки в складі виразу „аналітична форма”, використання його в інших виразах є метафоричним, неточним ${ }^{10}$.

У тлумаченні аналітизму на лексичному рівні постає актуальним послідовне розмежування відомих у мовознавстві видів словосполучень - вільних, стійких і фразеологічних.

Словосполучення, на думку В. Виноградова, - це сполучення слів, що організоване за законами даної мови і виражає певне складне поняття ${ }^{11}$.

Вільними вважають словосполучення, складові елементи яких зберігають свої лексичні значення та залишаються самостійними членами речення. Вони створюються за синтаксичними моделями щоразу заново, а не вносяться в мов-

${ }^{6}$ I. I. Ков а ли к, Словотвір сучасної української мови, Передмова, Київ 1979, с. 7.

7 А. П. Загні тко, Теорія сучасного синтаксису, Донецьк 2008, с. 227.

8 Там само, с. 228.

9 О. А. Дубова, Типологічна еволюиія морфологічних систем украӥнської і російської мов, Київ 2002, с. 31.

${ }^{10}$ И. А. Мельчук, Курс общей морфологии, Москва-Вена 1997, с. 334-335.

${ }^{11}$ В. В. В и ногр ад о в, Вопросы изучения словосочетаний (на материале русского языка), [в:] Избранные труды. Исследования по русской грамматике, Москва 1975, с. 242. 
лення в готовому вигляді. Значення вільних словосполучень виводиться з суми значень їхніх складових.

Стійкі словосполучення створюються за синтаксичними моделями, мають сталий порядок слів і вносяться в речення в готовому вигляді. Б. Михайлишин, наприклад, уважає, що стійкі словосполучення є проміжною ланкою між фразеологічними одиницями та вільними поєднаннями слів. Науковець із цього приводу зазначає, що чіткої межі між фразеологічними одиницями та сталими словосполученнями, з одного боку, й вільними поєднаннями слів і стійкими словосполученнями, з іншого, немає. Переважна більшість найменувань, узагальнених назвою „стійкі словосполучення”, репрезентовані неоднослівними термінами $^{12}$. Зазначений автор наголошує на тому, що ці та подібні поєднання містять безсумнівні елементи лексикалізації та водночас фразеологізації. „В окремі словосполучення вплітається елемент граматикалізації, спричинений компонентами передусім з кількісним значенням", - наголошує Б. Михайлишин ${ }^{13}$.

Термінологічне словосполучення є різновидом стійкого словосполучення, характеризується більш чи менш стабільним порядком компонентів, обмеженою заміною його частин. Елементи, що входять до складу термінологічного словосполучення, поєднуються за певними лексичними та граматичними правилами відповідно до закону валентності, тобто здатності входити до словосполучення при утворенні лексико-семантичного ряду слів ${ }^{14}$. Такі номінативні одиниці позначають одне складне, розчленоване поняття, володіють цілісністю значення та цілісністю номінації, напр.: зварювальний автомат, випрямний агрегат, ексиентрикова муфта, високовольтний генератор, мастильний бак, ротаційний копер, релейний модулятор ${ }^{15}$ тощо.

Термінологічні вільні словосполучення компонуються зі складових елементів, що мають термінологічне значення в певній терміносистемі. Елементи цих словосполучень можуть функціонувати як самостійно, так і входити до складу іншої терміноодиниці, напр., складовими частинами аналітичного терміна поперечне коло електромашинного підсилювача поперечного поля $\epsilon$ номінації поперечне коло, електромашинний підсилювач, поперечне поле; терміна комбінований мальтійський механізм з изікою на штовхачі кулачкового механізму - мальтійський механізм, кулачковий механізм. Терміни електромашинний підсилювач, мальтійський механізм є конструктивними елементами багатокомпонентних термінологічних одиниць електромашинний підсилювач з діаметральним кроком, електромашинний підсилювач послідовного самозбудження; мальтійський механізм з приводом кривошипа від диференціального механізму, мальтійський механізм зі стрибковим зубчатим барабаном ${ }^{16}$. Термінологічні вільні словосполучення відзначаються відносно вільним порядком розміщення складових, напр., багатошвидкісний асинхронний електричний двигун і асинхронний багатошвидкісний електричний двигун; активізована безцементна шлакова маса і безиементна активізована шлакова маса. Цілком

12 Б. П. Михайлишин, Лінгвістичний статус складених термінів, [в:] Vocabulum et vocabularium, Гродно 1998, вып. 5, с. 134.

${ }^{13}$ Там само, с. 134.

${ }^{14}$ Н. Місн и к, Аналітичні терміни у складі термінології клінічної медицини, [в:] „Українська термінологія і сучасність" Київ 2001, вип. 4, с. 15.

${ }_{15}$ Російсько-український словник з інженерних технологій, укл. М. Ганіткев ич, Б. Кінаш, Львів 2004, 1024 с.

${ }^{16}$ Національний банк стандартизованих науково-технічних термінів, [в:] Електронний реcypc: http://www.ukrndnc.org.ua. 
слушною є думка Л. Малевич про те, що такі словосполучення не повинні піддаватися кодифікації та стандартизації, досить того, що будуть уніфіковані терміни, які входять до їх складу ${ }^{17}$.

На сьогодні найбільш дискусійним є питання щодо статусу аналітичних термінів. У сучасному українському та зарубіжному мовознавстві існує кілька поглядів на співвідношення термінологічних словосполучень та фразеологічних одиниць. Одні дослідники розглядають термінологічні словосполучення як складову частину фразеологічного рівня мови (О. Ахманова, І. Білодід, М. Брицин, В. Виноградов, М. Шанський та ін.), представники іншого погляду заперечують правомірність розгляду термінологічних словосполучень як фразеологічних (Л. Авксентьєв, М. Алефіренко, Б. Головін, О. Кожин, Б. Ларін, Б. Михайлишин, Т. Панько, О. Толікіна, О. Чуєшкова та ін.). Дехто з дослідників зараховує до фразеології не всі складені найменування, а лише певну частину на основі їхньої стійкості та здатності відтворюватися в готовому вигляді (Л. Веклинець, В. Даниленко, В. Калашник, А. Коваль, С. Ожегов, О. Сербенська та ін.).

Підтримуємо позицію М. Алефіренка, Б. Михайлишина, О. Толікіної, О. Чуєшкової та інших науковців і вважаємо, що аналітичні терміни тільки зовні наближаються до фразеологізмів, але в структурно-семантичному плані $\epsilon$ номінаціями спеціальної сфери використання. Вони суворо обмежені складом терміноелементів і не здатні до синтаксичних видозмін своєї структури.

Понятійне поле більшості аналітичних термінів репрезентоване семантикою складників. Кожен член у структурі номінативної одиниці є „показником характерних властивостей означуваного, в кожному з них реалізується частка цілісної смислової єдності, основою якої є семантика всіх членів сполуки"'18, напр.: магнітогідродинамічний генератор - джерело, що безпосередньо перетворює теплову енергію на електричну шляхом взаємодії магнітного поля зі струмопровідними рідинами чи низькотемпературною плазмою; анкерне кріплення - кріплення, що є болтом (анкером), на одному кінці якого є клиновий замок, а на другому - опорна плита чи гайка; пазовий клин - пластина чи брусок, призначені для укріплення обмотки в пазові.

Важливим аспектом у дослідженні й вивченні аналітичних термінів $є$ ономасіологічний підхід - від змісту до форми, адже зміна наукових парадигм у лінгвістиці та їх інтеграція зумовила „висунення на перший план ономасіологічних аспектів аналізу фактів мови з домінуючим напрямком від інтенції (задуму) - до мовної форми реалізації'19.

Ономасіологічний підхід до вивчення аналітичних номінацій науковотехнічної термінології пов'язаний із виділенням трьох основних категорій, що визначають мотив позначення: 1) ономасіологічний базис, що вказує на певний понятійний клас (родове поняття); 2) ономасіологічна ознака, що позначає видові відмінності, які виділяють предмет усередині класу; 3) предикат (зв'язка), що пов'язує ономасіологічний базис та ономасіологічну ознаку і вказує на структури знання людини про навколишній світ.

Сучасні дослідження дають змогу говорити про можливість безпосереднього зіставлення структури, в якій ономасіологічну ознаку приписують оно-

17 Л. Д. Малевич, Становлення і розвиток украӥнської гідромеліоративноӥ термінологіï, Київ 1999, с. 121.

${ }^{18} \mathrm{O}$. В. Чує шкова, Аналітичні номінації в економічній терміносистемі (структурнотипологічний аспект), Харків 2002, с. 58. c. 7 .

${ }^{19}$ Ф. С. Бац ев ич, Т. А. Космеда, Очерки по функциональной лексикологи, Львов 1997, 
масіологічній структурі за допомогою ономасіологічного предиката 3 пропозиційною структурою мотиваційного судження та ії розгляду як особливого зразка репрезентації знань.

Ономасіологічним базисом $є$ поняття субстанції та іï різновиди (машини, пристрої, деталі, речовини, матеріали, приміщення, предмети, живі істоти тощо), а також дії, процеси, властивості, величини, одиниці виміру тощо. Як ономасіологічні ознаки виступають певні якості цих предметів, дій, процесів, властивостей, величин, їхні відношення та зв'язки. Так, у терміні трубонарізний верстат ономасіологічний базис верстат указує на машину для оброблення деталей або матеріалів (категоріальне поняття); ономасіологічна ознака трубонарізний має домінантну сему „нарізувати труби”. Ономасіологічний предикат цієї номінації визначаємо як „верстат, що призначений для нарізування різьби на кінцях заготівки”. Це можна узагальнити в ономасіологічній моделі „призначення, функційність” / „предмет”.

Ономасіологічні структури аналітичних термінів реалізуються в термінотворчих структурах, репрезентованих різними моделями. Як показав проведений аналіз фактичного матеріалу, більшість аналітичних термінів у досліджуваній термінології базована на ономасіологічних структурах 3 родо-видовим членуванням об'єкта номінації. Найбільш продуктивною є модель ,атрибут” / „предмет”, репрезентована на граматичному рівні моделлю прикметник (дісприкметник) + іменник. Зазначимо, що субкатегоризація головних понять науково-технічної термінології здійснюється завдяки терміноелементу, вираженому здебільшого прикметниками, меншою мірою дієприкметниками (армований бетон, ведений вал, ведений диск, відкрита дуга, закріплена балка, заломлена хвиля, напружений стан, нагрітий стан).

Зі структурного погляду ономасіологічний базис та ономасіологічна ознака можуть бути: 1) непохідні: (біла) [латунь], (червоний) [жар], (глуха) [муфma]; 2) похідні: (змішувальний) [хлипак], (стяжний) [утулок], (ущільнювальний) [вкладень]; 3) складні: (електродинамічний) [амперметр], (алюмосилікатні) [вогнетриви]; 4) складені: [вхідна напруга], (щзо викликає повзучість). Найбільшу частину в аналізованій термінології становлять різноманітні структурні комбінації ономасіологічного базису та ономасіологічної ознаки, що репрезентують змішаний тип: (важкий) [бензин], (бітумоплавильний) [агрегат], (припливно-витяжна) [вентиляція], (пневматичний / ударно-штамповий) [інструмент], [крива] (тиск-температура).

У процесі функціонування видова спеціальна назва часто перетворюється на родову. У такий спосіб формуються багатокомпонентні аналітичні терміни зі спільним базисним компонентом, що характеризуються вищим ступенем конкретизації лексичних значень слів, називаючи єдине поняття чи реалію. Так, на основі двокомпонентного терміна (гайковий / мутровий) [ключ], що позначає різновид знаряддя для загвинчування або відгвинчування мутри, прогоничів та інших деталей, унаслідок подальшої конкретизації значення утворилися терміни (розсувний) [гайковий ключ], (накидний) [гайковий ключ], (монолітний) [гайковий ключ], що, відповідно, стали конструктивною основою складніших термінів: (ріжковий) [монолітний гайковий ключ], (двосторонній) [ріжковий монолітний гайковий ключ]. Як зазначають учені, родові та видові найменування зі спільним базисним компонентом об'єднуються в гіперо-гіпонімічні парадигми.

Залежна частина багатокомпонентного терміна передає складну ономасіологічну ознаку, що вказує на кілька суттєвих характеристик поняття. Напр., 
у структурі номінації верхній кувальний штамп відображена класифікація поняття категорії предметів (штамn) за функціональною ознакою (кувальний) та локативністю (верхній). Поняття категорії виробничих дій та процесів у номінації ударні динамічні випробування деталізується за здатністю об'єкта піддаватися певній дії (ударні) та вказівкою на стосунок до чогось (динамічні).

3 урахуванням умов семантичного навантаження ономасіологічної ознаки можна зарахувати термін до різних формальних типів. Так, у номінації (багатошвидкісний) [асинхронний електричний двигун] ономасіологічна ознака багатошвидкісний тлумачиться як „кількість” і „прискорений темп дії”. Семантична структура ономасіологічного базису ускладнена семами „неодночасність”, „стосунок до чогось”.

За допомогою терміносполук, що описують результати пізнавальної діяльності людини, відображають роботу людської когніції, процесів категоризації й концептуалізації, можна найбільш повно відобразити когнітивні й психологічні механізми, що беруть участь у побудові мовної категорії. Категоризація мовного матеріалу відображає когнітивне тлумачення кожного слова, що демонструє особливу категорію чи категорії як одиниці певної ієрархічної системи, в якій спостерігаються гіперо-гіпонімічні відношення, а також системи, в якій зазвичай можна виділити так званий базовий рівень в таксономіці слів, відповідно до якого на вищих рівнях зазначаються абстрактні найменування категорії, а на нижчих - найбільш конкретні представники однієї і тієї самої категорії. Це можна проілюструвати на прикладах фрагмента категорії „машини, прилади, устаткування”. На базовому рівні цієї категорії виділяються такі різновиди машин для перетворення певного виду енергії, як двигун, генератор. На першому й другому субкатегоріальних рівнях у цих підкатегоріях виділяються конкретні видові машини, що позначаються відповідними термінами: двигун (толоковий) [двигун], (реверсивний) [двигун], (електричний) [двигун] (однофазний) [електричний двигун], (трифазний) [електричний двигун], (синхронний) [електричний двигун], (асинхронний) [електричний двигун] (багатошвидкісний) [асинхронний електричний двигун]; генератор (тепловий) [генератор], (ударний) [генератор], (електричний) [генератор] [електричний генератор] (з чітко виявленими полюсами), [електричний генератор] (з нечітко виявленими полюсами $)^{20}$.

Наголосимо, що дослідження науково-технічної термінології в межах когнітивного підходу передбачає вивчення процесу співвідношення думки з певною концептуальною категорією, виокремлення когнітивно-понятійних концептів професійної сфери знань або діяльності мовного колективу й визначення взаємозв'язку між знаннями й пізнанням, а також їх відображенням у мовних одиницях.

Отже, внаслідок аналізу ономасіологічної структури аналітичного терміна можна виявити зв'язки між базисом й ознакою, а також співвідношення мовних одиниць із концептуальною картиною науково-технічної галузі, з'ясувати, чи відбувається в процесі номінації позначення конкретного простого поняття, складної ознаки або сукупності ознак, чи має місце поступове введення властивостей у вже субкатегоризоване поняття.

Перспективи дослідження вбачаємо в подальшому вивченні аналітичних термінів зазначеної термінології в когнітивно-ономасіологічному аспекті 3 метою встановлення залежності між мовним оформленням, концептуальною структурою терміна та його місцем у системі відповідних номінацій.

${ }^{20}$ Російсько-украӥнський загальнотехнічний словник, ред. Л. І. Мац ь ко, Київ 1994, с. 173. 